\title{
К ПРОБЛЕМЕ АКСИОЛОГИЧЕСКОЙ ДЕСКРИПЦИИ ЖАЛОСТИ В РУССКОМ ЯЗЫКЕ
}

\author{
ON THE PROBLEM OF AXIOLOGICAL DESCRIPTIONS OF PITY \\ IN RUSSIAN
}

\author{
ЛАРИСА НИКОЛАЕНКО
}

\begin{abstract}
The author argues that the Russian language world-view verbalizes a dual assessment of pity. Moral assessment of pity as the soul's immediate response to someone else's suffering is positive. However, the uncomfortable and even painful process of experiencing this emotion and the high degree of intensity of its influence on one's psyche results in a negative hedonic evaluation of pity. This explains the metaphorical conceptualization of pity in images of pain, aggressive power, water element, and fire.
\end{abstract}

Лариса Николаенко, Институт языкознания им. Александра Потебни НАН Украины, Киев - Украина, larysanik@ukr.net

Среди психологов не существует однозначного мнения относительно классификации жалости. Одни ученые считают эту эмоцию положительной, другие - отрицательной. Все зависит от типа оценки, применяемой при классификации. Если берется во внимание моральная или этическая оценка, соотносимая с понятиями добра и зла, то чаще всего жалость рассматривается как положительная эмоция, близкая к любви и состраданию. Русский философ Владимир Соловьев утверждал, что „внутренним основанием нравственного отношения к другим существам [...] может быть только жалость, или сострадание" 1 . Гедонистическая или сенсорная оценка, связанная с душевными и телесными ощущениями субъекта во время переживания эмоции, довольно часто оказывается негативной, так как проявления жалости могут быть дискомфортными и даже болезненными для субъекта. В русской лексикографической практике толкование жалости происходит посредством ее идентификации с близкими эмоциями, ср.: жалость - „1. Сострадание, сочувствие; 2. устар. простореч. Горесть, пе-

1 В. С. С о л о в ь е в, Оправдание добра. Нравственная фрилософия. Сочинения в 2-х т., т. 1, Москва 1988 , с. 52. 
чаль" 2 , „чувство сострадания к кому-, чему-либо”3, „сострадание, сожаление, сочувствие человеку в его беде"4. Мы, вслед за Ириной Левонтиной, эту эмоцию рассматриваем как „мгновенную реакцию души на чужое страдание" 5 .

Целью нашей статьи является описание оценочных характеристик жалости в русской языковой картине мира на основе анализа контекстной сочетаемости существительного жалость в русских художественных текстах. Материал исследования получен из Национального корпуса русского языка ${ }^{6}$ методом автоматического поиска. В своей работе мы будем исходить из того, что аксиологическую характеристику жалости составляют два типа оценки - моральная, соотносимая с понятиями добра и зла, и гедонистическая, связанная с приятными и неприятными ощущениями ${ }^{7}$. Эти оценки объективируются в языке метафорическим способом при помощи концептуальных признаков и образов.

Позитивная моральная оценка жалости в русском языке выражается при помощи антропоморфных признаков, характеризующих эмоцию как человеческое существо, исходя из которых жалость может быть нежная, добрая, сердечная, ласковая, кроткая, безумно-трогательная, трогающая душу, благоговейная, слезливая, плачущая, виноватая, совестливая, родственная; см. примеры: „Но теперь уже не раздражение, глядя на них, почувствовал Арефьев, а тихую, нежную, родственную жалость" (А. Куприн, По заказу); "- Морозка... - тихо позвал Мечик, остановивиись против него и переполняясь Вдруг слезливой доброй жалостью к нему и $к$ этой мертвой кошади” (А. Фадеев, Разгром); „Томность, уныние и какая-то трогающая душу жалость разливались по бледно-белому лицу ее" (П. Львов, Даша, деревенская девушка); „Ребенок беспомощен и доверчив, он бесстрашен, потому что верит в любовь, он беззащитен и вызывает жалость, но не унижающую, а ласковую, теплую жалость" (митрополит Антоний (Блум). Последнее содержание жизни).

2 Словарь современного русского литературного языка: 817 m., т. 4, Москва-Ленинград 1950-1965, с. 25.

3 Большой толковый словарь русского языка, ред. С. А.Кузнецов, Санкт-Петербург 1998, с. 299.

4 Т. В. Л е т я г о в а, Н. Н. Р о м а н о в а, А. В. Ф и л и п п о в, Тысяча состояний души: краткий психолого-филологический словарь, Москва 2005, с. 111.

${ }^{5}$ И. Б. Л е в о н т и н а, Помилосердуйте, братиы!, [в:] Ключевые идеи русской языковой картины мира, Москва 2005, с. 271.

${ }^{6}$ Национальный корпус русского языка, [в:] электронный ресурс: http://www.ruscorpora.ru (17.05.2015).

7 О языковой оценке эмоций см. в частности: А. M i k o 1 a j c z u k, Problem ocen w analizie wybranych polskich nazw uczuć z klasy semantycznej GNIEWU, [в:] Język a kultura, t. 14: Uczucia w języku i tekście, Wrocław 2000, c. 117-134. 
Позитивная моральная оценка жалости может усиливаться упоминанием о сопутствующих позитивных чувствах: ^юбовъ, нежность, доброта, сердечность, сочувствие, сострадание, сожаление, участие, милосердие; см. примеры: „Меня залила, затопила жалость и любовь к нему” (3. Масленикова, Жизнь отцуа Александра Меня); „Параскеве опять стало грустно, и теплая волна жалости и любви настигла ее душу на самом распутье, когда не знала уже она, как себя повести и как подойти к сыну" (В. Личутин, Обработно - время свадеб); „Она [Наташа] опять заплакала. И еще больше чувство жалости, нежности и ююбви охватило Пьера" (Л. Толстой, Война и мир); „Маруся-облако хотела что-то сказать мне, но мы говорили на разных языках, я только чувствовала любовь, жалость, нежность, бесконечное сожаление, беспредельную печаль” (Н. Галкина, Вила Рено); „Сердие Ромашова дрогнуло от жалости и любви” (А. Куприн, Поединок); „Он [Юрий] почувствовал $к$ сестре нежность и неопределенную тихую жалость" (М. Арцыбашев, Санин); „А Мавра Кузьминишна еще долго с мокрыми глазами стояла перед затворенною калиткой, задумчиво покачивая головой и чувствуя неожиданный прилив материнской нежности и жалости к неизвестному ей офииерику” (Л. Толстой, Война и мир); "Катя осторожно садилась рядом с мужем и гладила его руку. Ее заливала нежность и жалость к нему” (А. Толстой, Хождение по мукам); „Впечатление же было поистине угнетающее: $b$ первый раз $b$ жизни я видела человека умного, доброго, но несчастного, как бы Всеми заброшенного, и чувство глубокого сострадания и жалости зародилось в моем сердие [...]" (А. Достоевская, Воспоминания); „Начальники службы индивидуальной безопасности всегда вызывали у него чувство жалости и сострадания" (А. и Б. Стругацкие, Далекая Радуга); „Тень сочувствия или жалости тронула сердие Командора..." (В. Астафьев, Царь-рыба); „Агасфер Вместе с микующей рабской толпой идет по пыльной раскаленной улице, взбирается на Голгофу и вдруг чувствует, что на него упал кроткий, страдальческий взгляд, полный милосердия, сострадания, жалости" (Е. Соловьев-Андреевич, Л. Толстой. Его жизнь и литературная деятельность); „Мое сердие было полно сочувствия и жалости $\kappa$ Достоевскому, перенесшему ужасную жизнь каторги" (А. Достоевская, Воспоминания).

Несмотря на превалирующую позитивную моральную оценку жалости, нужно отметить наличие двойственного морального оценочного суждения о ней. Эта эмоция может негативно оцениваться с позиции объекта эмоционального переживания вследствие стереотипного представления о жалости к самому себе со стороны других как о чем-то унижающем, ср. примеры: „Жалость не следует смешивать со здоровым, активным началом сочувствия. Это особое переживание $\boldsymbol{b}$ другом унижения, Втайне применяемого к себе" (Л. Гинзбург, Записные книжки. Воспоминания. Эссе); „Он поглядел на нее, и злоба, выразивиаяся на 
ее лище, испугала и удивила его. Он не понимал того, ито его жалость к ней раздражала ее. Она видела в нем к себе сожаленье, но не любовь" (Л. Толстой, Анна Каренина); "Не смотрите так, ваша жалость убъет меня" (И. Гончаров, Обрыв); „Слова его долго производили на меня потом, при воспоминании, тяжелое впечатление какой-то странной, презрительной $\kappa$ нему жалости, которой бы я вовсе не хотел ошущать" (Ф. Достоевский, Идиот).

Феномен жалости заключается в том, что человек может переживать ее не только по отоношению к тем, к кому он чувствует любовь, нежность, симпатию, но и относительно тех, кто вызывает пренебрежение, отвращение, презрение. Как свидетельствуют языковые данные, моральное оценочное суждение о жалости в русском языковом сознании приобретает негативную окраску в случаях актуализации ее вместе с такими негативными чувствами, как: ненависть, враждебность, гнеһ, неприязнь, пренебрежение, отвращение, брезгливость, презрение, снисхождение; см. примеры: „Ходасевич [...] с какой-то жалостью, смешанной с отвращением, вспомнил, как эти девочки в лохмотьях и во вщах облепили его [...]" (Н. Берберова, Курсив мой); „Помада с горьким соболезнованием сообщил о пьянстве Розанова и Лизе [...] - Несчасный человек! - сказала Лиза с жалостью и с презрением. - Так он и пропадет" (Н. Лесков, Некуда); "Пьер, выйдя в коридор, с жалостью и отврашением смотрел на этого полусумасшедшего старика" (Л. Толстой, Война и мир); „Лицо ее [Марианны] находилось в почти черной тени, но так вопросительно, так настойчиво глядели на Нежданова ее смелые глаза, такое презрение, такую обидную жалость выражали ее сжатые губы, что он остановился в недоумении" (И. Тургенев, Новь); „Им овладело то истинно министерское чувство высокомерной жалости и гадливого снисхождения, которое столь свойственно петербургскому сановному люду” (И. Тургенев, Новь); "Александра Михайловна села к окну и задумчиво уставилась на темневший двор. "Жалко Танечку», - думала она. Но жалость была больше $b$ мыслях. В душе с жалостью мешалось брезгливое презрение к Тане” (В. Вересаев, Два конца); „[...] Анна $[\ldots]$ поняла, что никакая сила $b$ мире не заставит ее теперь изменить свое отнотение к Жаку. Это было чувство и враждебности, и презрения, и жалости к нему” (Г. Газданов, Пробуждение); "Проживет она с этим гигиенистом все свои деньги", - грубо подумал Самгин, и чувство жалости $\kappa$ матери Вдруг окрасилось неприязнью к ней" (М. Горький, Жизнь Клима Самгина); "Совсем тряпка-тряпкой стал. Обидно за него, горько, и ненависть к нему и брезгливость [...] А иногда замечаю, что он как-будто робеет меня. Явно избегает раздеваться при мне и искаться. Когда застаю его за этим занятием, вид у него пойманного школьника. Сразу поднимается острая жалость, ненависть и отвращение” (С. Семенов, Голод); „Ужас, отвращение, жалость, гнев перемешивались и сплетались в какой-то тя- 
желый психический ком, свинцовым грузом придавливавший всю жизнь чувства и воли" (В. Чернов, Записки социалиста революиионера).

Негативные сопутствующие чувства могут объективироваться в виде антропоморфных признаков, которые также репрезентируют негативную моральную оценку жалости: жалость - брезгливая, снисходительно-брезгливая, насмешливая, презрительная, постыдная, унижающая, обидная, высокомерная; см. примеры: „В глазах его было даже не презрение, а какая-то брезгливая жалость, смешанная с откровенным удивлением" (А. Городницкий, И жить еще надежде); „Встречи с Сережей будят во мне зверя. Я бы даже, наверное, ударил его, но сдерживает какая-то постыдная жалость” (В. Панюшкин, Тетеринское); „Им овладело то истинно министерское чувство высокомерной жалости и гадливого снисхождения, которое столь свойственно петербургскому сановному пюду" (И. Тургенев, Новъ); "Я жалел Лапова, жалел брезгливой, но обязывающей к помощи жалостью, которой стыдился [...]" (Г. Сабуров, Пешком по волнам); „Спал он на худшем месте во всем бараке - у входной двери, где его обдавало холодным сквозняком и где одно время стоял огромный ушастый чан с гремящей крышкой - параша. Русские заключенные называли Иконникова „старик-парашютист", считали его юродивым и относились к нему с брезгливой жалостью" (В. Гроссман, Жизнь и судьба); "Слова его долго производили на меня потом, при воспоминании, тяжелое впечатление какой-то странной, презрительной к нему жалости, которой бы я вовсе не хотел ощущать" (Ф. Достоевский, Идиот); „Лицо ее [Марианны] находилось в почти черной тени, но так вопросительно, так настойчиво глядели на Нежданова ее смелые глаза, такое презрение, такую обидную жалость выражали ее сжатые губы, что он остановился $b$ недоумении" (И. Тургенев, Новъ); ", - Вот еще истеричка! - сказал он с презрительной жалостью. - Это же обман чувсть, наваждение. Я тоже первую неделю все слышал голос жены" (Ю. Домбровский, Факультет ненужных Вещей); "И к любви мальчика начало примешиваться сначала недоумение, потом какая-то презрительная жалость" (А. Атеев, Солние мертвых).

Гедонистическая оценка жалости, связанная с приятными и неприятными ощущениями, как показал языковой материал, чаще всего оказывается негативной, поскольку переживание этой эмоции может быть дискомфортным и даже болезненным для субъекта. Иными словами, жалость - это не только мгновенная, но и болезненная реакция души на чужое страдание. Этим можно объяснить языковую концептуализацию жалости в образах боли, агрессивной силы, водной стихии, огня. Представленные образы отражают также стихийность эмоции, высокую степень интенсивности ее воздействия на субъект:

жалость - боль (душевная, физическая): жалость - острая, болезненная, щемящая, тяжелая, исступленная, нестерпимая, невыносимая, не- 
утолимая, ноющая, мучительная, пронзительная, пронзающуая, колющуая, тягостная; жалость давит (пронзила) сердие, кольнула в сердие, сжала спазмой горло; муки (судорога) жалости; от жалости сердце болело (стеснилось, (за)ныло, (за)щемило, корчится, рвалось, разрывается, надрывается, рвется на куски, кровью обливалось), навернулись (полились) слезы, сморшуиось лицо, стянуло горло, защемило все внутри; от жалости вскрикнуть (зарыдать, (за)плакать, сморщиться, всхлипывать, содрогаться, страдать, задыхаться, сжаться, надрываться); жалостью сердие щемит (защемило, пронзается, снедалось, надрывается, растравляется); жалостью терзаться, сердие надрывать; см. примеры: „Нестерпимая жалость пронзила мое сердце, снова началось у меня михорадочное состояние" (Л. Вертинская, Синяя птица ююбви); "А у Митьки 8 горле судороги, жалость к этим как будто чужим ююдям, жалость до жгучей боли, до точного удушъя [...]” (М. Шолохов, Бахчевник); "Это исхудавшее страдальческое мицо, эти запекшиеся, синие губы, этот восковой лоб, эти спутанные в беспорядке седые кудри - я едва узнавала их. Острая жалость пронзила сердие. Стоя у изголовья неподвижно лежащего отиуа, испьтывая непосильную муку жалости, сострадания и раскаяния, я шептала мысленно те самые слова, которые не сумела сказать накануне нашей разлуки” (Л. Чарская, Вторая Нина); „Острая, как боль, жалость охватила Ланде: он всем телом повернулся к Семенову и обнял его обеими руками за худые, пахнущие холодным потом, плечи" (М. Арцыбашев, Смерть Ланде); "Почти физически чувствую, как сердце корчится от боли, от пронзительной жалости к молодым и старикам" (Е. Гинзбург, Крутой маршрут); „Болезненная жалость по отношению к сыну давит сердиее (В. Спектр, Face Control); „Ведь он и сам ююбит ее, или, по крайней мере, жалеет по временам внезапною и безнадежною, острою до боли, нестерпимою жалостью” (Д. Мережковский, Петр и Алексей); "Антон редко видел ее слезы: она не была плаксой... В нем поднялась волна острой, как физическая боль, жалости, захлестнула его и бросила к ней [...]" (И. Безладнова, Дина); "[...] и снова сжала сердие тягостная жалость, снова подкатил к горлу знакомый ком, снова задрожал вдруг подбородок" (Б. Васильев, Не стреляитте В белых лебедей); „Боль эта была усилена еще тем странным чувством физической жалости к ней, которую произвели на него ее слезы” (Л. Толстой, Анна Каренина); "У меня вдруг прямо защемило все внутри от жалости к этой женщине и мальчику, просто так, не знаю почему” (В. Аксенов, Апельсины из Марокко); "Когда солдаты во время войны видели голодних детей, у них от жалости и сострадания серие кровъю обливалось” (С. Аксаков, Записки ружейного охотника); „Спиридон смотрел на жену и видел, что ей уж не встать, и она сама знает это, а все-таки продолжает заботиться о нем. И опять горе и жалость кчелоВеку, с которым прожил целую жизнь, сжала ему спазмой горло" (П. Романов, Голубое платье); "Она сказала это таким несчастным голосом, что от 
жалости к ней у Юрки стянуло горло [...]" (С. Каледин, Записки гробокопателя); „Терпимов, исхудавиий и побледневиий до неузнаваемости, с забинтованной рукой, покоивщейся на черной перевязке, вошел в класс. Едкое чувство жалости защемило мне сердие... Непрошеные слезы обожгли глаза" (Л. Чарская, Записки институтки);

жалость - агрессивная сила: жалость - свирепая, страшная, дикая, лютая, иарапающая, колючая, остроклювая, жуткая, безумная, смертельная, гнетущая, захлестываюшая, хватавшая за душу, разрывающая (рвущая) сердие; жалость обуревает (мучает, терзает, раздирала, резанула, душила, захлестнула, схватила, пронзила, охватила) кого-то; жалость распирает (кольнула, гложет, сжала, стиснула, сдавила, стеснила, пронзила, разрывала, давит, терзала, когтила, прошила) сердие, схватила за сердие (за горло), пронзает сердие до самих пяток, хватала за душу, скребла (пронизала) душу, рвала на части, долбанула под сердие, сжала (сдавила, стиснула) горло, ударила в сердие, сжимала грудь, вгрызалась в сердие (грызла сердие) как зверь; чувство жалости душит, охватило, сжимало сердие; удары (уколы) жалости; игла жалости; см. примеры: „Уже не ужас чувствовал я: жалость несказанная стиснула мне сердие” (И. Тургенев, Живые мощи); „Нищая страна окровавлена. И вдруг пронизывает чувство, которое так и останется основным чувством, пронизывает, перерезая горло, - жалость. К кому? К этим одураченным людям?” (Б. Вахтин, Гибель Джонстауна); „ИВернеВ впервые Видел свою мудрую, спокойную мать такой подаһленной. Мучительная жалость сдавила ему горло. Он не смог произнести ни слова и только молча стоял, вопросительно глядя на нее” (И. Ефремов, Лезвие бритвы); „Страдая за всех и за каждого в отдельности, Мышка плохо спала, в тревожные ночи огромная жалость разрывала ее сердие, топила $b$ слезах подушку" (В. Осеева, Динка); „А я не могу говорить, охватила меня и давит жалость к человеку, живым во гроб положенному" (М. Горький, Исповедъ); "Илья держал письмо в руке и чувствовал себя виноватым пред Олимпиадой, грусть и жалость сжимали ему грудь и давили горло" (М. Горький, Трое); "И опять остроклювая жалость долбанула меня под сердие" (А. Пастернак, Сонька-помойка); "Анна подошла к нему, заглянула В мицо: глаза его были липко зажмурены, на оскаленных плотных зубах искрилась слюна, редкие, вывалявшиеся от тифа волосы лежали на лбу мокрой прядью. Она присела рядом. Жалость и боль когтили ее сердие" (М. Шолохов, Тихий Дон); „Совсем дурачок, блаженненький! Ну, как такого казнить?” - подумал Петр, и вдруг дикая, страшная, лютая жалость вгрызлась ему в сердие, как зверь" (Д. Мережковский, Петр и Алексей); „Жалость, точно рогатина, ударила $b$ сердие Андрея" (Б. Шергин, Древние памяти); "Я посмотрела на его невзрослую макушку, и $\boldsymbol{b}$ мое сердие Вошиа игла жалости" (В. Токарева, Центтовка); „, - Бедный, бедный! - Нели буквально раздирала жалость" (Т. Тронина, Никогда не говори „навсегда"); 
жалость - огонь: жалость - жгучая, огненная; жалость вспыхнула, обжигала сердие, загоралась в сердие; чувство жалости сожгло сердие дотла; от жалости зажигается за грудиной; жалостью ожгло, загоралось сердие, занималось место в груди; см. примеры: „Жалость и горькое чувство вины обжигали сердие” (Б. Екимов, Высшая мера); "Иван Дмитриевич почувствоВал, как у него зажигается за грудиной от жалости к сыну и ненависти $\kappa$ жене” (Л. Юзефович, Дом свиданий); „И острое чувство жалости к девушке сожгло дотла, казалось, сердие Дуни" (Л. Чарская, Приютки); „На секунду она, видимо, забыла о своем затекшем глазе, и взгляд получился больной и несчастный, как у дворовой собаки. Я отвернулся, меня будто ожгло жалостью" (С. Есин, Марбург);

жалость - водная стихия (с температурными признаками): жалость - обильная, бурная, клокочущая, затопившая, прорвавщая все плотины; жалость разлилась (захлестнула, залила, затопила); волна жалости ударила В сердие, см. примеры: „Ночью Татьяна Васильевна не спала. Горячая, обильная жалость, наконец-то прорвавшая все плотины, заливала её изнутpu” (И. Грекова, Под фонарем); "И, взглянув на друга, почувствовал Гулявин, как ударила ему $в$ сердие горячая волна жалости" (Б. Лавренев, Ветер); "Что-то больно сжало сердие корректорши. Горячая волна жалости хлынула $b$ душу" (Л. Чарская, Корректорша Варкунина); „Меня вдруг захлестнула жгучая жалость к Моте, к ее висящим вдоль тела грубым рукам, которые были еще грубее и неуклюжей без работы" (Е. Маркова, Тайная Вечеря); "И вдруг какая-то колючая жалость так и хлынет во все фибры существа" (М. Салтыков-Щедрин, За рубежом); „Горячая волна жалости и вины за свое бессилие сшибла Стаса с ног" (Е. Михайлова, Исповедь на краю).

Переживание жалости, ассоциируемой с горячей жидкостью, не всегда вызывает дискомфортные ощущения и, следовательно, не всегда оценивается негативно, ср. примеры: „[...] во мне вдруг разлилась какая-то горячая жалость ко всем и ко всему, что я видел, о чем думал и чем беспокоился в последнее время” (Г. Успенский, Волей-неволей); „Голос его звучит так нежно, так грустно поет он над плачущей Катей, что Динка глубже зарывается в кусты, и горячая жалость приливает кее сердиу" (В. Осеева, Динка); „И снова горячая волна жалости хлынула В сердие Даши” (Л. Чарская, Первыи денъ); „Но когда он увидел ее, одинокую и согнутую, все существо его переполнилось светлой нежностью и жгучей жалостью” (М. Арцыбашев, Смерть Ланде); „Даже беспечная, жизнерадостная Дося почувствовала, как должен был сейчас страдать ее друг. Горячая волна жалости залила ее маленькое сердие" (Л. Чарская, Большая душа); ассоциация жалости с теплой жидкостью всегда воспринимается позитивно, ср. примеры: „Трупа Артем не испугался, только ошутил, как теплой волной накатила жалость к неизвестной девушке" (Д. Глухов- 
ский, Метро 2033); „Параскеве опять стало грустно, и теплая волна жалости и любви настигла ее душу на самом распутье, когда не знала уже она, как себя повести и как подойти к сыну" (В. Личутин, Обработно - время свадеб); "Женя почувствовал, как на него накатывается теплая волна мелодраматической жалости" (С. Дубянский, Госпожа Клио. Заходящее солнцее); „Волна жалости к ним и себе окутала Нину, такая теплая волна, как ватное одеяло” (Э. Аленник, Напоминание); „И помимо его желания и Воли в душе у Умара вдруг возникла теплая волна жалости к этому человеку" (Г. Черчесов, Прикосновение).

Как ни парадоксально, но довольно часто в аксиологической дескрипции жалости могут присутствовать одновременно обе оценки - моральная позитивная и гедонистическая негативная, см. примеры: „Таню забила как 8 лихорадке такая нежная, острая жалость, какая и редко пробуждается к людям, скорей же - $к$ больному животному, котенку, щенку" (И. Новиков, Гарахвена) (негативная гедонистическая оценка - острая жалость забила как в лихорадке, позитивная моральная оценка - нежная жалость); „Тонкая, глубокая нежность и какая-то болезненная жалость к матери переполнила сердие Буланина" (А. Куприн, На переломе) (негативная гедонистическая оценка - болезненная жалость, позитивная моральная оценка - сопутствующее чувство нежность); „ИВан Афрриканович взглянул на жену и вдруг Весь сжался от боми, жалости и ююбви к ней: он только теперь заметил, как она похудела, как изменилась за это лето" (В. Белов, Привычное дело) (негативная гедонистическая оценка - сжался от боли, жалости, позитивная моральная оценка - сопутствующее чувство ююбовь); „Острая, мучительная жалость и беззаветная любовь наполнили мое сердие при виде так незаслуженно обиженной мною подруги" (Л. Чарская, Княжна Джаваха) (негативная гедонистическая оценка - острая, мучительная жалость, позитивная моральная оценка - сопутствующее чувство любовъ); „Его лицо выражало такое отчаяние, мольбу и страх за свое святотатство, что болезненная, щемящая, но Вместе с тем сладкая жалость наполнили душу девушки..." (М. Волконский, Кольио императрицы) (негативная гедонистическая оценка - болезненная, щемящая жалость, позитивная моральная оценка - сладкая жалость); „Коленька видит его страдания, и нежная боль, нежнейшая жалость к отиу пронзает его" (Ю. Анненков, Повесть о пустяках) (негативная гедонистическая оценка - жалость и боль пронзает, позитивная моральная оценка - нежнейшая жалость); „А Маша внимательно смотрела на нее и чувствовала рвушую сердие нежную жалость к этой Нюсе [...]" (К. Симонов, Живые и мертвые) (негативная гедонистическая оценка - рвущая сердие жалость, позитивная моральная оценка - нежная жалость); „Горячее до слез чувство ююбви и жалости к ней и к себе самому больно сжимало старое 
умирающее сердие Ивана Ивановича, когда он, опираясь на нее, волочился через зал" (М. Арцыбашев, У последней черты) (негативная гедонистическая оценка - горячее до слез чувство жалости больно сжимало сердие, позитивная моральная оценка - сопутствующее чувство ююбовъ); „Завтра воскресенье. Завтра похороны. Ночью Татьяна Васильевна снова лежала без сна, поставив будильник, чтобы не проспать. Жалость и любовь, рвавшие её на части прочлой ночью, теперь поутихли, но спать она не могла!" (И. Грекова, Под фонарем) (негативная гедонистическая оценка - жалость рвавиая на части, позитивная моральная оценка - сопутствующее чувство любовь); „Ты сказал такую несуразииу, что меня всю внутри пронзила такая острая жалость, такая любовь к тебе, что захотелось твою голову прижать к груди, затискать, как ребенка" (М. Шишкин, Венерин волос) (негативная гедонистическая оценка - пронзила острая жалость, позитивная моральная оценка - сопутствующее чувство любовъ); „Любовь и горькая жалость были во мне” (В. Вересаев, К жизни) (негативная гедонистическая оценка - горькая жалость, позитивная моральная оценка - сопутствующее чувство ююбовъ).

Оценка вкусовых характеристик жалости может быть бинарной: жалость может быть как горькой - негативно оцениваемой, так и сладкой - оцениваемой позитивно, ср. примеры: „Любовъ и горькая жалость были во мне” (В. Вересаев, К жизни); „Ювентин слушал объяснения Евандра и думал, что все это похоже на бред; сердие его сжималось от горькой жалости" (Д. Мережковский, Смерть богов. Юлиан Отступник); "Я догадался, что гардемарин меня пожалел, и впервые узнал, что жалость оставляет $в$ душе горъкий осадок" (К. Паустовский, Книга о жизни. Далекие годы); "Его лицо выражало такое отчаяние, мольбу и страх за свое святотатство, что болезненная, щемящая, но вместе с тем сладкая жалость наполнили душу девушки..." (М. Волконский, Кольио императрицы); „[...] красота начинала будоражить острее, разрозненные звуки сплетались в мелодию - и всё внутри заполняла тягучая, как ириска, сладкая жалость" (К. Аручеан, Полководец Соня, или В поисках Земли Обетованной); „В его глазах - горькая жалость к себе” (В. Шишков, Угрюм-река).

Проведенный анализ языковой объективации аксиологической характеристики жалости в русской языковой картине мира позволяет утверждать, что она осуществляется метафорическим способом и представляет собой два типа оценки - моральную и гедонистическую. С точки зрения морали жалость как мгновенная реакция души на чужое страдание оценивается позитивно и считается основанием нравственного отношения к другим существам. Однако, несмотря на превалирующую позитивную моральную оценку, эта эмоция может оцениваться негативно с позиции объекта эмоционального переживания вследствие стереотипного представления о жалости к самому себе со 
стороны других как о чем-то унижающем. В отдельных случаях негативно коннотируемая жалость бывает близка к отвращению или презрению. Дискомфортное и даже болезненное переживание жалости субъектом, интенсивность и стихийность эмоции являются причиной ее негативной гедонистической оценки. Этим можно объяснить языковую концептуализацию жалости в образах боли, агрессивной силы, водной стихии, огня.

\section{Библиография}

Большой толковый словарь русского языка, ред. С. А.Кузнецов, Санкт-Петербург 1998.

Л е в о н т и н а И. Б., Помилосердуйте, братцыы!, [в:] Ключевые идеи русской языковой картины мира, Москва 2005, с. 271.

Л е т я г о в а Т. В., Р о м а н о в а Н. Н., Ф и л и п п о в А. В., Тысяча состояний dyши: краткий психолого-филологический словарь, Москва 2005.

M i k o ł a j c z u k A., Problem ocen w analizie wybranych polskich nazw uczuć z klasy semantycznej GNIEWU, [в:] Jezzyk a kultura, t. 14: Uczucia w języku i tekście, Wrocław 2000, c. $117-134$.

Национальный корпус русского языка, [в:] электронный ресурс: http://www.ruscorpora.ru (17.05.2015).

Словарь современного русского иитературного языка: $b 17$ m., т. 4, Москва-Ленинград 1950-1965.

С о л о в ь е в В. С., Оправдание добра. Нравственная философия. Сочинения 6 2-x m., т. 1, Москва 1988. 
